\title{
The Role of the Spirit in Romanesque Iconography. Jaca's Tympanum Reinterpretation
}

\author{
Dominique J. Persoons
}

\section{ABSTRACT}

The role of the Holy Spirit was considerable during the Romanesque period, and its importance remained unknown for a long time. Illuminations could contribute to restoring an appropriate understanding of church settings. The perspective of a powerful and hidden Spirit reveals a new perspective on the tympanums of some famous Romanesque churches.

\begin{abstract}
Résumé— Le rôle de l'Esprit Saint était considérable à l'époque romane, et son importance est restée longtemps inconnue. L'analyse de certaines enluminures contemporaines pourrait être précieuse, même pour interpréter certains décors d'église. La mise en perspective de la croyance médiévale en des esprits nombreux donne un nouveau regard sur les tympans de quelques églises romanes célèbres.
\end{abstract}

Keywords: Holy Spirit, double soul, Plato, Jaca, Lème.
Published Online:September13,2021

ISSN: $2736-5514$

DOI :10.24018/theology.2021.1.5.31

\section{J. Persoons}

G. Hosp. Saverne, Affiliate University of Strasbourg, France.

(e-mail: pers00ns@aol.com)

*Corresponding Author

\section{INTRODUCTION}

Medieval spiritual exuberance is not a strictly European invention but was imported as early as the second century AD by the Hellenistic culture open to Chaldean and Persian influences. In addition, the philosophy of cloisters and abbeys was essentially Platonic, and the three-part soul nourished the metaphysical imagination until the early thirteenth century when it was gradually supplanted by Arab rational philosophers and the original writings of Aristotle.

\section{Platonism in the Medieval Monasteries}

After the fall of the Roman Empire, metaphysical research began in Spain and Italy as early as the sixth century AD. The reflection was nourished by the Holy Scriptures and some ancient texts, the most important of which, Plato's Timaeus, Calcidius translated into Latin in the fourth century AD. The translations of Meno and Phaedron did not appear until 1156, and Proclus was not translated and commented on until 1350 [1], [2]. Jean Scott (Erigene) [3] the philosopher of Charlemagne, is in part responsible for using Platonism to translate Christian dogma into a rational and intellectual language. He is also credited with translating and commenting on the Syrian Pseudo-Dionysius the Areopagite. These authors contributed to return to philosophy and autonomous speculation, and also search for Truth for itself. "We commented on Plato as we commented on the Bible, on the search of speaking enigma", Abelard said, who was "as familiar to philosophers as it is to prophets. Everything Plato said about the soul of the world must be understood in an enveloped sense (per involucrum) [4]". This term "enveloped" was already used by Pseudo-
Dionysius the Areopagite [5]. Jacques Darriulat [6] in his "Introduction to Plato's Philosophy" reports the Plato's words:

Housed in the skull, Reason-Noùs is in the part of the body which is closest to the celestial regions. The other two parts of the soul, separated from the higher principle, are pushed back into the thorax. But since one is superior to the other, they are in turn separated by the diaphragm, which ensures their mutual independence. As, of this soul, a portion was by nature better and the other worse, the divine craftsman further divided the thorax cavity into two dwellings: he separates them, as one separates the apartment of women and that of men, and he places the diaphragm in the middle of them, like a partition... As for Epithumia, it is housed on the lower level, below the diaphragm which corresponds to the level of the navel (Timaeus, 69c-70 b).

Several Spanish or French twelfth century crucifixes show a spiral navel, such as in Saint Peter of Siresa in Aragon, Christ 1147 from the Museu Nacional d'Art de Catalunya in Bracelona, Santo Cristo del Milagro de Burgo de Osma (Spain), Christ in Majesty from Rodez and the tympanum from the church of Vandeins in the Ain (France).

\section{BYZANTINE INFLUENCE}

The philosophical doctrines of the Hellenistic period were enriched by contributions from the eastern Chaldean and Persian cultures. From the first century AD, Christian apologists appropriated the pagan method of allegorical 
interpretation, which the Jewish prophets also employed. Indeed, free interpretation indeed allowed them to discover in "the poetic fictions of the ancient Greek philosophers the most sublime theories of Christianity". Psellos in the twelfth century even compared God to Jupiter: "The mighty monarch who reigns in the sky is Jupiter who is the first to advance in a winged chariot, arranges and rules all things [7], [8]". As proof, we can see on the north facade of Saint Mark's Basilica in Venice [9] a bas-relief that depicts Alexander the Great carrying a royal miter on his head and standing on a chariot to attached to two fantastic animals: the body of a lion with the head and wings of an eagle, to say griffins, typically considered Persian mythical animals. Alexander, the illustrious Greek general, represents the human soul (Psuchè) ascending to the sky pulled by two griffins which represent the double spirit. The writings of Plato and persistent contact with Byzantium -which imported sibylline and mysterious though from Persia and Babylon- influenced the monastic philosophy from the seventh to twelfth centuries.

According to Endre von Ivánka [10] the epistemology of Neoplatonism is characterized by "the universal intertwining of the world of Ideas", the principle according to which "realities become particular and divide when descending the scale of beings and become general and unify when bringing up". This is visible on the tympanum of Fownhope Church, where the foliage is divided at the bottom, and grouped into two bouquets at the top, from which we can conclude that foliage represents ideas.

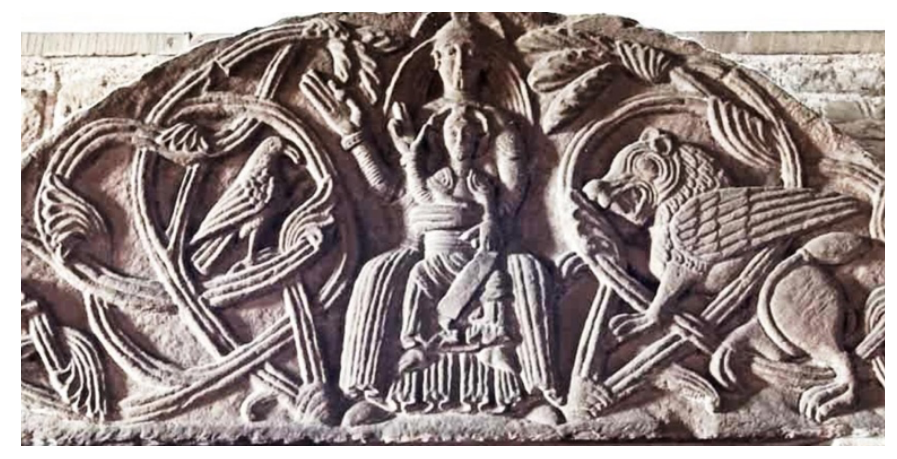

Fig. 1. Tympanum of Fownhope church in England. Madonna and Child circa 1140. By the universal intertwining of the world of ideas, the principle according to which realities become particular and divide when descending

the scale of beings and become general and unify when bringing up.

The overall effect is more Byzantine than Northern European. The heavy pleated costume - a feature of the Herefordshire School - also has a Byzantine appearance [11]. We note the interweaving of foliage (allegory of ideas) which are concentrated at the top in two spiritual bouquets. The foliage branch downwards and become more complex and converge in at the top. On the right, a winged lion evokes anima with obviously Persian imagery, and on the left the bird clearly evokes spiritus. The present symbol would therefore be God as Mother [12] with her son Mens inspired by anima the force and spiritus the Genius, a double language between Christian faith and Greek metaphysics.

\section{THE HARVEY-MS-4951 FOL.123 ILLUMINATION}

The manuscript Harley-MS-4951 (from the British Library) consists of two volumes; the second comes from the Saint-Etienne cathedral in Toulouse (France) and is dated to the first quarter of the thirteenth century. It is a religious music libretto, with a little-known illumination. Folio $123 \mathrm{r}$. shows Christ in Majesty surrounded by the four Evangelists. The image also shows a large $X$, which could represent the Holy Spirit. It is an exceptional document that represents the Trinity as it existed in the imagination of the thirteenth century, with a Holy Spirit composed of two opposing forces that intersect. In illumination Harley-MS-4951, God the Father is shown in the center, in the form of a blue disc inhabited by an intricate, purely spiritual foliage (the foliage is "bodiless"). Jesus the Son is below, seated on his throne. The $X$ of the Holy Spirit connects the Father above to the Son below. The right branch of the $X$ is decorated with a small brown head belonging to a charming mouse. This mouse could be the representation of spiritus- divine love. A blue head, determined and threatening appears above the left branch of the $X$.

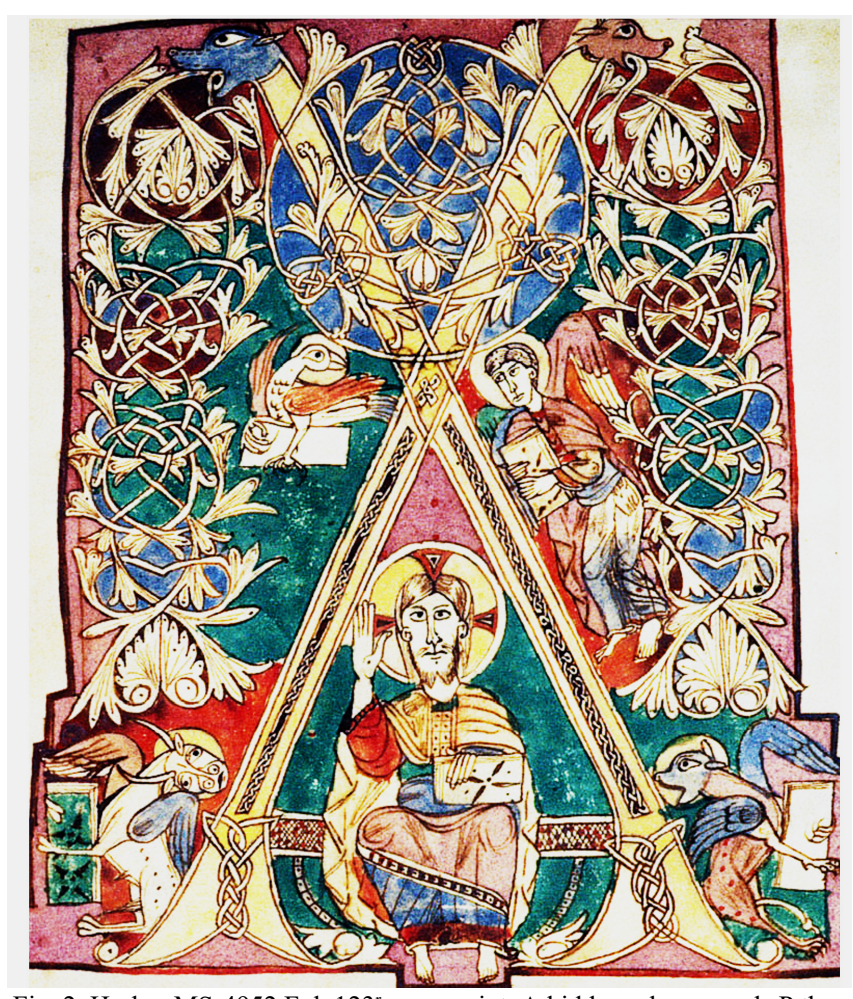

Fig. 2. Harley-MS-4952 Fol. $123^{\mathrm{r}}$ manuscript. A hidden rebus reveals $P$ the blue disc, $\mathrm{A}$ Jesus, and $\mathrm{X}$ the Holy Spirit $=$ PAX.

Michael Camille [13] and Jacqueline Leclercq-Marx [14] note the use of symbolic mice in the Middle Ages. Mice burrow, proof of their connection to the earth (and to the underworld). Some accounts say that the mouse came out of the mouths of the dead and carried the soul to the next world [15], [16]. Two examples of this imagery are mice gnawing the terrestrial globe, the "rat ball" [17] (like on the left wing of Saint Germain l'Auxerrois church in Paris) and the medieval proverb Ore, mus, dominates mundi: with the mouth, rat, master of the world. W. Deonna [18] specifies that: 
The Church warns the faithful that they must, from their birth, think about the brevity and uncertainty of their life, curb their earthly appetites, avoid the easy seductions of this deceptive world, which destroy their soul, like time destroys their bodies, as rodent rats destroy the world, that they must think about salvation.

They Harley document consist of three different parts. At the top, a richly decorated bluish disc would evoke God the Father. Under him, Jesus the Son sits on a throne. He is framed by the two arms of the $X$ which cross above him and then ascend, crossing the blue disc of the Father. They $X$ ends with two symbolic animals higher than God the Father. A spiritual foliage also surrounds the evangelists. Marie Formarier [19] describes it in this way:

First of all, as J. Hamesse [20] underlines, the medieval conception of the imaginatio and of the phantasia is directly linked to the psychological doctrines concerning the faculties and the powers of the soul.

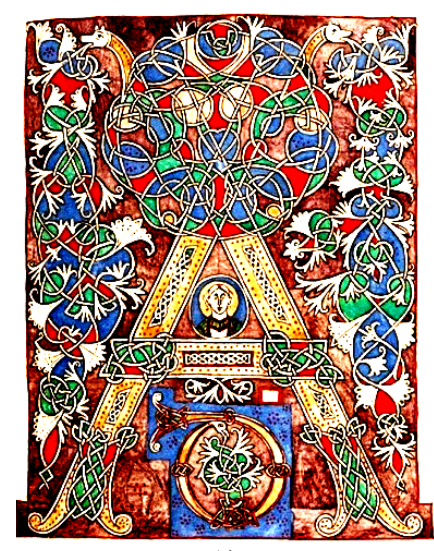

A)

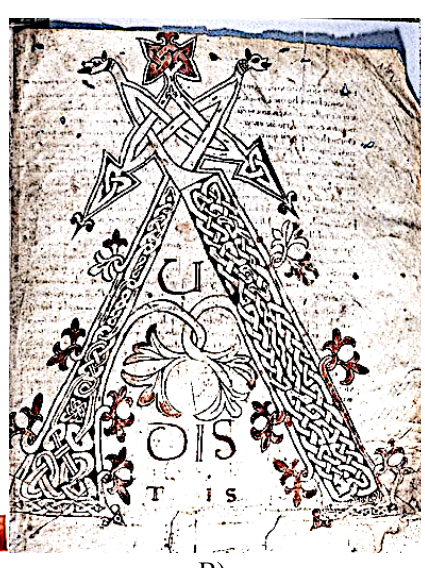

B)
Fig. 3. A) Gradual Albiense, BNF-Latin-MS-776 fol. $005^{\mathrm{v}}$, twelfth century B) Clermont Ferrand-MS- 1512 fol. $001^{\mathrm{r}}$ eleventh century.

\section{Plato's Chiasma}

Semantics of the chi seems to date back to Plato and was the result of two opposing principles. Plato left behind a dichotomous soul [21]. In his Republic IV, he describes the two forces [22] that compose that chi: Thumos represents both bravery and anger, it is represented by the Sun. Epithumia represents the dark side of soul, love, or mysterious passions. It is represented by the Moon. The famous allegory of the hitch explains how the soul is to be led by a wise guide (Logistikon) who towers over his two horses Thumos and Epithumia, one white and one black. The theologian Jean-Marc Prieur [23] quoted, in 1998, Saint Justin the Martyr, one of the first Christian theologians of the second century AD:

Plato deals with the soul of the World and explains that it was split lengthwise into two strips and that these strips were attached to each other, crisscrossed in the middle in the shape of a $\chi$. They were then curved so that they meet on the opposite side and form two concentric circles. So that the soul of the World surrounds the sphere of the
Universe ... The soul of the World has been imprinted in the Universe as a $\chi$. According to Plato, the Son of God

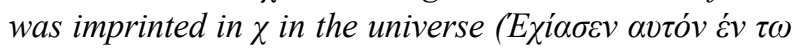
$\left.\pi \alpha v i^{\prime}\right)$... but from an erroneous reading of the account of the erection of a figure of the cross. Plato also perceived the existence of the Spirit, he assigned him the third place ... Thus, the son of God extends bodily to the dimensions of the Universe and this extension is done according to a mode which evokes the crucifixion, and not in the form of a $\chi$ as Plato claimed.

A)
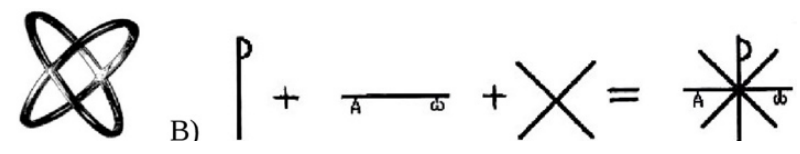

Fig. 4. A) The cosmic soul of Plato, described by Justin in the second century AD: "According to Plato, the Son of God was imprinted in $\chi$ in the universe". B) The construction of a chrismon according to Esteban Lorente. P the Father, A- $\omega$ the son, and X the Spirit.

Larry W. Hurtado [24] quotes this same paragraph in 2018:

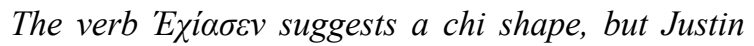
claims (1 Apol. 60:2-5) that Plato derived the idea from a misunderstanding of the account where Moses was directed by God to erect a brass object for the healing of the Israelites who had been bitten by serpents (Num. 21:8-9).

This dualism of consciousness was essential in constructing Christianity. It is certainly of Platonic origin, but allowed Christianity to escape the grip of Manichaeism, freed in the Roman Empire following the Edict of Milan in 313 [25]. Platonic dualism avoided giving in the single Manichean thought which would have deprived man of his "freedom of Conscience". Augustine of Hippo who later converted to Neoplatonism, made this essential contribution. To quote Robert Javelet who, in 1959 [26], evoked the "Psychology of the spiritual authors of the twelfth century":

According to Hugh of Saint-Victor [27], all admit metaphysical dualism. It has the filigree of Platonism. The soul is the body rider. To tell the truth, it has an ambiguous situation on two planes: as a spiritual substance centered on the beings which really exist (intellectibilia), it is spiritus; as the animating principle of the body, it is anima. It lives in herself through the intellect and brings the body to life through sensitivity.

In 1993, Esteban Lorente [28] proposed an explanatory diagram of the Romanesque chrismons, particularly that of Jaca's Cathedral (Fig. 4 b). The X (chi) represents the Holy Spirit, which Iryna Lystopad [29] confirmed in her thesis on Platonism in the twelfth century. The $\mathrm{P}$ is the vertical axis and represents Pater (the Father), and the Son is the horizontal axis which is made up of the letters alpha and omega. The Spirit forms a second oblique cross. 


\section{ReVOlution IN THE THIRTEENTH CENTURY}

Jérôme Baschet [30] expounds on this subject:

Thirteenth century scholasticism and St. Thomas both clearly state that the Spirit [spiritus] and the soul [anima] are one and the same. It is still the scholasticism of the thirteenth century which, considering a unique soul endowed with three powers [Mens, spiritus and anima], offers one of the best resolutions to this contradiction...

Consider that the first decree of the 1274 Council [31] was to prohibit the double Nature of the Spirit:

1274: first decree: On the Supreme Trinity and the Catholic Faith: The Holy Spirit proceeds eternally from the Father and the Son, not from two principles, but as from a single principle; not by two spirations, but by a single spiration; and we condemn and reprove all who claim to deny that the Holy Spirit proceeds eternally from the Father and the Son, or recklessly assert that the Holy Spirit proceeds from the Father and the Son as two [different] principles and not as one alone.

The Council of 1274 banished the double Holy Spirit from the Catholic religion. By contrast, two centuries earlier monastic psychological philosophy was still universally recognized. The dual Spirit made part of the Christian faith in the twelfth century [32]-[34]. Adding various letters to change the meaning of this poem of Jaca's Cathedral would be a modernist initiative. If we trust the hemistich instead, we will find a historically consistent explanation:

\section{P Pater, A Genitus / duplex is Spritus Almus:}

P. the Father, A. the Son / the Holy Spirit is twofold.

By the time of this poem (eleventh century), a dual Holy Spirit was very probably obvious.

VII. Platonic Dualism in the Twelfth CENTURY
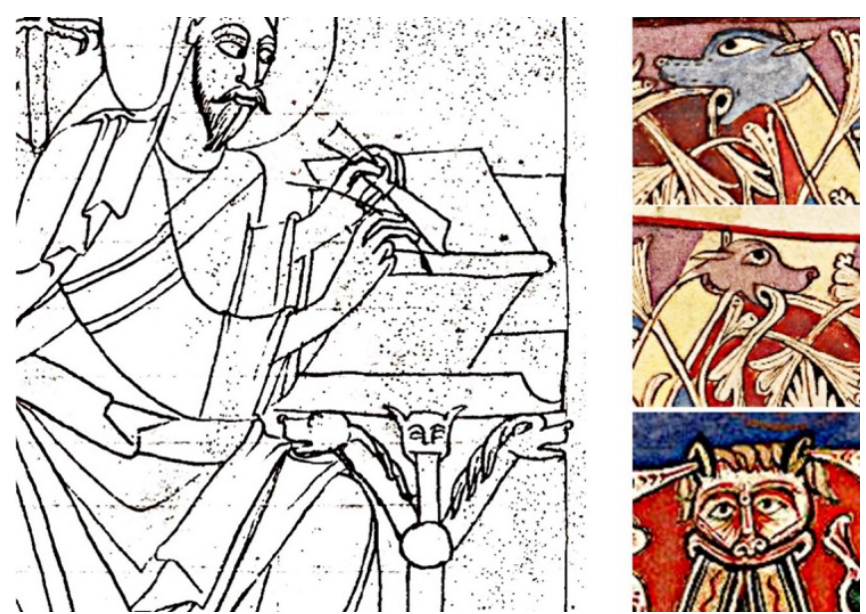

Fig. 5. Manuscript Metz-MS-0035 fol.4v : God's son is writing on a tripod topped with three symbolic heads.

The Metz 0035 fol. $4^{\mathrm{v}}$ manuscript provides further proof. God is writing, leaning on a three-post table. This table has two mouse heads, which symbolise Anima and Spiritus, and the head of the bugger, in the centre, symbolises Reason (Mens).

We again note the resemblance between these mouse heads and the Harvey-MS-4951 manuscript. This image reveals the symbolic value of Romanesque icons because the monk who drew it left philosophical symbols. God's son is a copyist himself, and he works at his desk with a pen in his right hand and a knife in his left hand. His parchment is balanced on the faith of men. This faith rests on three pillars. One menacing mouse head appears on the top of one upright, an affectionate mouse head on another, and a third with a bugger swallowing the main upright. Those three heads give a description of Plato's soul. From the ninth century on, monks often referred to their work as "true philosophy" because they dedicated their lives to understanding the Christian message. "More generally, before the twelfth century the word "Theologia" was not widespread in monastic circle" [35] Iryna Lystopad wrote.

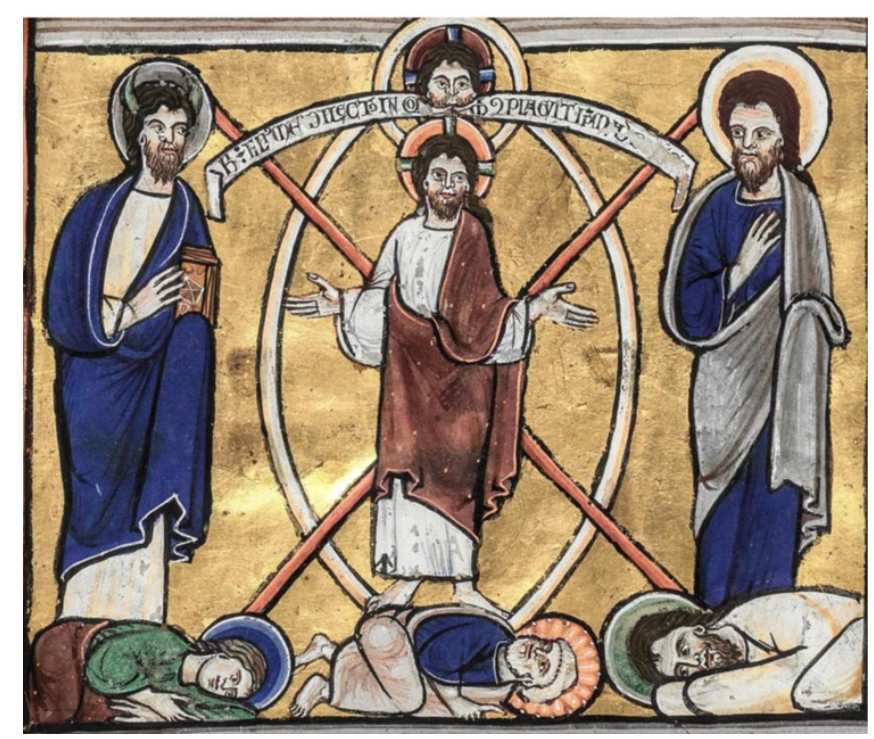

Fig. 6. The Canterbury Psalter Arundel-MS-157 manuscript fol. $7^{\mathrm{v}}$ : Mens, anima and spiritus are lying on the ground. The Holy Spirit is divided, Anima is the sun, and the divine Verb is the Moon.

The manuscript "Canterbury Psalter" dated around 1180, referenced Arundel-MS-157, which is a psalter of the Virgin Mary. The origin of this manuscript is unknown, but it probably has some connection with Oxford. This manuscript shows God the Father, God the Son, and apparently the Holy Spirit in the shape of an $X$. At the bottom of this $X$ are the three parts of the soul: anima on the left (a female figure), spiritus on the right (a male figure with a body totally hidden and therefore invisible) and Mens (an older character with a richly decorated halo), meaning Reason. God the Father and God the Son are above. On both sides, the sacred Anima resembles the Sun and the sacred Spiritus resembles the Moon, with its black crescent-shaped halo. Both are greater than Jesus Christ. The Canterbury Psalter, which frames the Christian divinity, God the Father and God the Son demonstrates the importance of the Holy Spirit in the twelfth century. The central divinity resides in a Mandorla, which itself rests on human Reason. The Double Spirit frames this halo.

This complex image is connected by an $X$, the fruit of Greek thought. This exogenous provenance of the $\mathrm{X}$ 
reinforces the strangeness of this Spirit who was not originally Christian [36] but Platonic Greek. To reconcile this contribution of Greek philosophy, Christianity have constantly reinvented their religion over the centuries. Historically, the third person in God has fueled theological disputes. Indeed, the spirit could be bad or good, only the Holy Spirit was divine. This explains the tradition of mistrusting laugh [37] in the Middle Ages. So, Hugh of Saint Victor [38]: "I judged the laughter to be a mistake". Alexis de Fontbonne [39] argues the following:

Thus, spiritus, superior to the body (to which are linked joy, the serpent and the desire for the superfluous) does not in any way constitute the highest part of man. Indeed, what makes the superiority of man, is God created the reasonable spirit to make it a participant of his Beatitude... The term spiritus therefore designates an element, distinct from the body and which was endowed by God with reason.

\section{IS JACA'S TYMPANUM DUALISTIC?}

Lème village is located in the French Bearn region. His tympanum is one of the most mysterious chrismons. To date, is there no explanation for the two characters surrounding this chrismon which is square and therefore less cosmic than terrestrial. It corresponds to the opposition between the right side and the left, and therefore to dualism. The hand that holds the axis of the Logos and its arm, come from a man on the right, whose gaze is hidden. This man on the right is invisible according to the medieval code of gaze described by Jérôme Baschet et al. [40]. He therefore represents Spiritus.

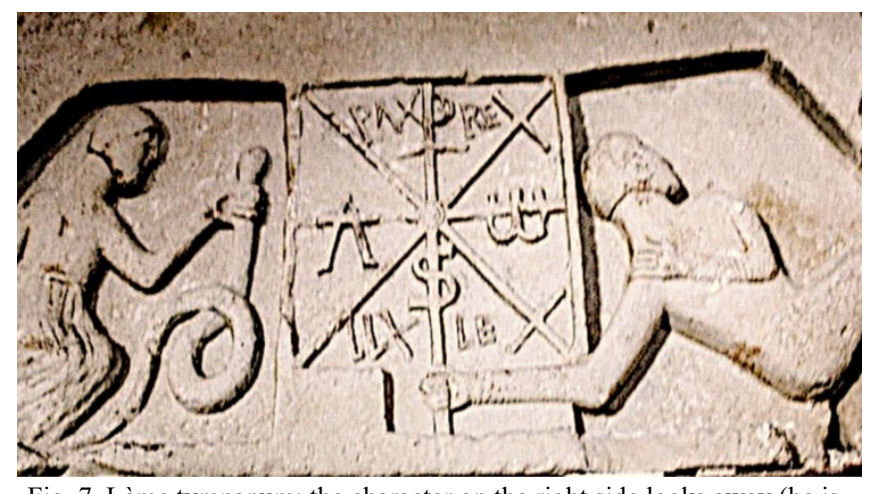

Fig. 7. Lème tympanum: the character on the right side looks away (he is "invisible" according to the Romanesque code) [41].

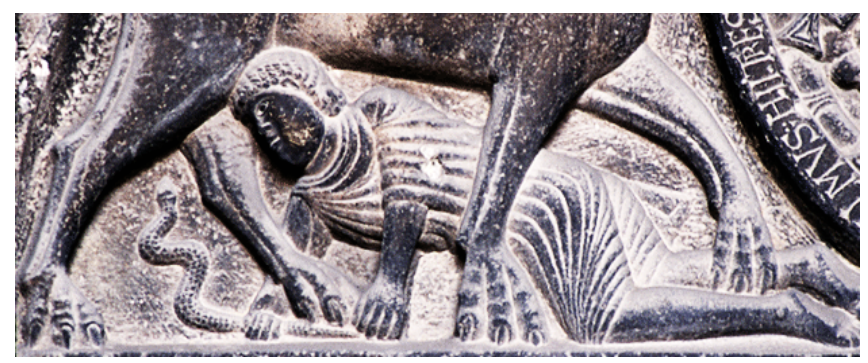

Fig. 8. In Jaca, the left character fights also the serpent, with the same significance: the will, the courage of anima.

The Lème chrismon (Fig. 7) depicts a dualism between anima on the left and spiritus on the right. In the center, the square chrismon would symbolise the double human Nature, marked by the two forces that cross it. The figure on the left corner of Jaca's tympanum also fights the snake. Its semiotic nature is anima. This hypothesis assumes the same scenography as in Lème. In those two tympanums, character on the left is attacking the tempting demon. He represents strength, thus anima. Regarding the tympanum of Jaca's Cathedral, Marcel Durliat [42] wrote:

At the moment when the cathedral of Jaca begins to emerge from the ground, that is to say immediately after 1090, the representation of the man with the snake is known in the artistic milieu where the great explosion of Romanesque sculpture is being prepared.

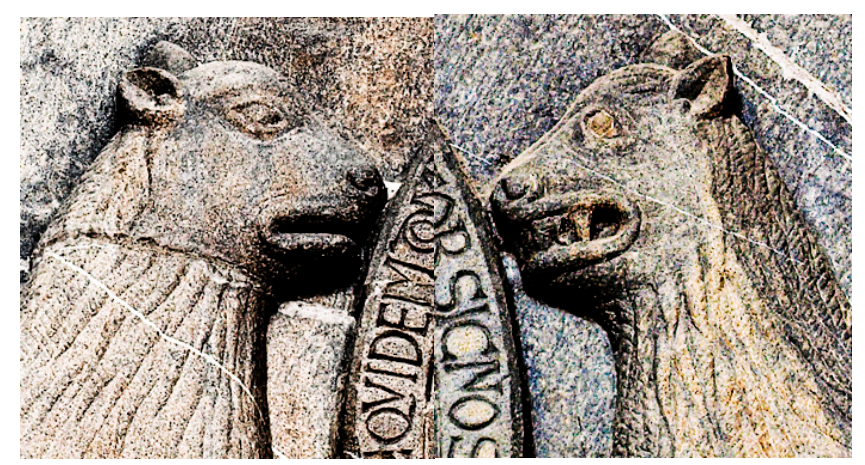

Fig. 9. The Jaca's tympanum depicts two lions with opposite expressions. The ears, the eyes and the mouths are different. Photo courtesy of Mr. Antonio Garcia Omedes [44].

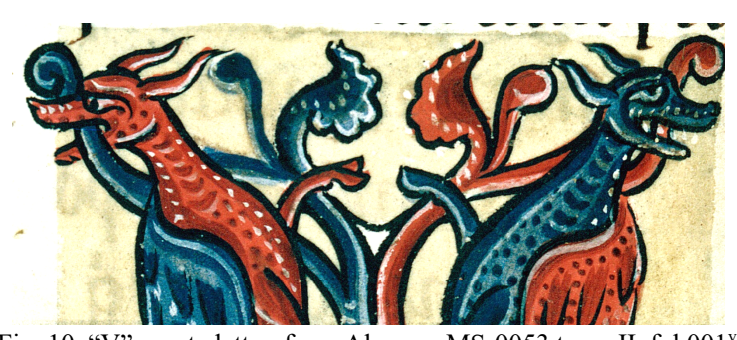

Fig. 10. "V" ornate letter, from Alençon-MS-0053 tome II, fol.001" manuscript: anima (left), and spiritus (right) like in Jaca.

Anne Marie Bautier reports the General Cartulary of the Hospitallers of Saint John of Jerusalem [43]: "We expel the fiery serpents by a simple sign of the cross, that is to say the evil spirits". The fight against the serpent is physical. The tympanum of Lème therefore takes up the well-known theme in Romanesque times of the "tempting serpent", just as in the tympanum of Jaca, and both symbolise anima, the sensitive component of the Holy Spirit.

In Jaca, as in Lème, the tympanum should be dualistic, showing the double nature of the Holy Spirit. This mentally $\mathrm{X}$ scenography should have been usual on the Romanesque tympanums until 1274. As expected, the lion on the left seems domineering, he shows threatening character with his cold gaze, prone ears, and tight mouth. The verse above the lion states: "The lion knows how to spare the one who is lying on the ground, and Christ the one who implores him". This evokes a very human feeling, related to strength (defeat) and honor (forgiveness), anima. The lion on the right offers a protective gaze, his ears are pricked up, his eyes are touching, and he bares his teeth. The verse above the right lion states: "The strong lion tramples the empire of death". Here is the victory of the Spiritus over physical death, that is 
to say metaphysics, spiritus the divine love, like a mother defends her cubs [45]. Therefore, Jaca's tympanum looks also dualistic.

\section{CONCLUSION}

The semantics of the two opposite lions of Jaca is the same as the Harley-4951 manuscript with the tender and the threatening mice. The tympanum therefore reflects a dualistic theology: The Holy Spirit is double; it is composed of anima human strength and divine love spiritus. This dualism was found in churches as well in manuscripts from the 11 th to the 13 th centuries.

\section{REFERENCES}

[1] http://www.yumpu.com/fr/document/read/13730978/4-lesprit-1-le lieu-de-la-mystique-reseau-regainnet.

[2] De Libera Alain, 2017, "la Philosophie médiévale", Que sais-je, Puf.2017.

[3] Ibid. https://www.yumpu.com/fr/document/read/13730978/4.

[4] https://philosophie.cegeptr.qc.ca/wp-content/documents/Laphilosophie-du-Moyen-\%C3\%82ge-1949.pdf.

[5] Perczel Istan, 1999, "Une théologie de la Lumière: Denys l'Aréopagite et Evagre le Pontique", Revue des Études Augustiniennes, 45, 79-120.

[6] http://wwwjdarruliat.net/Auteurs/Platon/Introduction/Platon Introd3.html.

[7] Zervos Ch., idem p-185-187. "The mighty monarch who reigns in the sky is Jupiter who is the first to advance in a winged chariot, arranges and rules all things. He is followed by the army of gods and demons, divided into eleven sections... The allegorical explanation of the texts had strongly seduced Psellos... God remains invisible to all those who allow themselves to be guided by the senses and the imagination. Only the shining eye of the soul, the contemplative spirit of one who is in ecstasy, can obtain the vision of God".

[8] "Therefore the kingdom of heaven is like a king who wanted to settle accounts with his servants." Matthew 18:23.

[9] Arrechie Alberto "San Michele Pavia, il volo di Alessandro", https://www.liutprand.it/articoliPavia.asp?id=564.

[10] Lystopad Iryna, 2016, "Un platonisme original au XIIe siècle" Thèse de philosophe, Institut de recherche et d'histoire des textes, CNRS.

[11] http://www.greatenglishchurches.co.uk/html/fownhope_gallery.html.

[12] Bynum Caroline Walker, 1984, "Jesus as mother: studies in the spirituality of the High Middle Ages", center for Medieval and Renaissance Studies, UCLA, Berkeley-Los Angeles-London.

[13] Camille Camille Michael, 1992, "Image on the edge: the margins of medieval art", Essays in Art and Culture, Published by Reaktion Books, pp 11-18.

[14] Leclercq-Marx Jacqueline, 2018, "Des souris, des saints et des mauvais souvenirs " Revue belge de philologie et d'histoire, tome 96, fasc. 2, 569-579.

[15] https://www.lefrontal.com/symbolique-de-la-souris.

[16] Nobecourt Lorette, 2013, "La clôture des merveilles: Une vie d'Hildegarde de Bingen", Grasset.

[17] Deonna Walter, 1958, "La boule aux rats et le monde trompeur", Revue Archéologique, 1, 55-75.

[18] Ibid. Deonna Walker, 1958.

[19] Formarier Marie, "Représenter et persuader dans la rhétorique exemplaire cistercienne", Rhuthmos, 25, juin 2014, http://rhuthmos.eu/spip.php?1227.
[20] Hamesse Jacqueline, "Imaginatio et phantasmia chez les auteurs philosophiques du XII et XIIIe siècles", in : Fattori I Bianchi M., Phantasia Imaginatio, Roma, Edizione dell'Ateneo, 1988, p 153-184.

[21] Mumen "les trois parties de l'âme chez Platon", blog: La philosophie qui vient, http://www.mumen.fr/les-trois parties-de-lame-chez-platon/ le $10 / 01 / 2021$.

[22] Pradeau Jean-François, 1998, "L'âme et la moëlle", archives de philosophie, 61, pp. 489-518. JSTOR, jstor.org/stable/43037688 Les Grecs avaient découvert la notion physique de forces. Ils considéraient que l'âme était comme le mat d'un navire soutenu par deux haubans exerçant des forces opposées, d'où l'invention de la méta-physique.

[23] Prieur Jean-Marc, avril-juin 1998, "La dimension cosmique de la crucifixion du Christ et de la croix dans la littérature chrétienne ancienne, ", Revue d'histoire et de philosophie religieuses, 78, 2, 3956.

[24] Hurtado Larry Weir, 2018, "The staurogram in early christian manuscripts: early visual reference to the crucified Jesus?" Text and artefact, biblical studies, Bloomsbury T\&T Clark.

[25] Seston William, 1980, "De l'authenticité et de la date de l'édit de Dioclétien contre les Manichéens", École française de Rome,43, 551560.

[26] Javelet Robert, 1959, : "Psychologie des auteurs spirituels du XIIe siècle ", Revue des sciences religieuses, Le Roux, Strasbourg, 5-9.

[27] Hugues De Saint-Victor, 1096-1141.

[28] Lorente Estaban, 1993, "Las inscriptionnes del timpano de la cathedral de Jaca", Artigrama n ${ }^{\circ} 10,143-161$.

[29] Lystopad Iryna, 2016, "Le Platonisme original au XIIe siècle', Thèse de philosophie, CNRS Le 05/09/2020.

https://www.theses.fr/2016EPHE5105. Le 15/11/2020.

[30] Baschet Jérôme, 2000, "Âme et corps dans l'Occident médiéval : une dualité dynamique, entre pluralité et dualisme", Archives de sciences sociales des religions, 112, 5-30.

[31] http://salveregina.com/index.php?title $=2 \% \mathrm{C} 3 \% \mathrm{~A} 8 \mathrm{me}$ _concile_de_L yon_1274, le 2/01/2021.

[32] De Saint-Victor Hugues (1096-1141) : "Il existe deux vies, l'une terrestre et corporelle, l'autre céleste et spirituelle : l'une par laquelle le corps vit de l'âme, l'autre par laquelle l'âme vit de Dieu",

[33] Javelet Robert, 1959, "Psychologie des auteurs spirituels du XIIe siècle, Revue des sciences religieuses, 33-3, 209-268.

[34] Bazzama André, Berou Nicole, Guichard Pierre, 2005, "Averroès et l'Averroïsme', collection d'histoire et d'archéologie médiévales", Presse universitaire de Lyon, France.

[35] https://bvmm.irht.cnrs.fr/iiif/23559/canvas/canvas-2270193/view.

[36] Ibid. Lystopad Iryna, "Le platonisme original au XIIe siècle".

[37] Huizinga Johan, 1919, "Le déclin du moyen âge", édition originale en néérlandais en 1919, Payot Paris, 2002.

[38] Hughes de Saint Victor, "In Salomonis Ecclesiasten Homiliae", 19, 8, Cf. J. Horowitz et S. Menache, L'humour en chaire. Le rire dans l'Église médiévale, Genève, 1994, p. 22, 34.

[39] De Fontbonne Alexis, 2016, "La référence à l'Esprit Saint de la réforme grégorienne au XIVe siècle", Thèse de doctorat, Paris Nanterre. https://www.theses.fr/2016PA100037.

[40] Baschet Jérôme, Bonne Jean-Claude, Dittmar Pierre-Olivier, 2012, "Le monde roman, par-delà le bien et le Mal", Les éditions Arkhê, 154.

[41] Garnier Antoine https://atlas-roman.blogspot.com 12/01/2021.

[42] Durliat Marcel, 1978, "Les origines de la sculpture romane à Jaca", Comptes rendus des séances de l'Académie des Inscriptions et BellesLettres, $122^{\circ}$ année, 2, 363-399.

[43] Delaville Le Roulx, "Cartulaire général de l'ordre des Hospitaliers de Saint-Jean de Jérusalem", t. I, Paris, 1894, 290, p. 213 (a. 1160-1178) ct no $634,431$.

[44] https://www.cincovillas.com/antonio-garcia-Omedes nuevomiembro-de-la-real-academia-de-nobles-ybellas-artes-de-san-luisde-zaragoza/.

[45] Bynum Caroline Walker, 1984, "Jesus as mother : studies in the spirituality of the Middle Ages", center for Medieval and Renaissance Studies, UCLA, Berkeley- Los Angeles- London. 